\title{
Correction to: Physician-directed genetic screening to evaluate personal risk for medically actionable disorders: a large multi-center cohort study
}

Eden V. Haverfield ${ }^{1 *}$, Edward D. Esplin ${ }^{1}$, Sienna J. Aguilarr ${ }^{1}$, Kathryn E. Hatchell ${ }^{1}$, Kelly E. Ormond ${ }^{2}$, Andrea Hanson-Kahn², Paldeep S. Atwal ${ }^{3,4,5}$, Sarah Macklin-Mantia ${ }^{3}$, Stephanie Hines ${ }^{3}$, Caron W.-M. Sak ${ }^{6}$, Steven Tucker ${ }^{6}$, Steven B. Bleyl ${ }^{7}$, Peter J. Hulick ${ }^{8}$, Ora K. Gordon ${ }^{9,10}$, Lea Velsher ${ }^{11}$, Jessica Y. J. Gu ${ }^{11}$, Scott M. Weissman ${ }^{7,12}$, Teresa Kruisselbrink ${ }^{13}$, Christopher Abel $^{14}$, Michele Kettles ${ }^{14}$, Anne Slavotinek ${ }^{15}$, Bryce A. Mendelsohn ${ }^{16}$, Robert C. Green ${ }^{17,18,19,20}$, Swaroop Aradhya ${ }^{1}$ and Robert L. Nussbaum ${ }^{1,21}$

\section{Correction to: BMC Med 19, 199 (2021)} https://doi.org/10.1186/s12916-021-01999-2

The original article [1] contained numerous typos which were mistakenly carried forward by the team that managed production of this article.

These errors have since been corrected.
Published online: 03 November 2021

\section{Reference}

1. Haverfield EV, Esplin ED, Aguilar SJ, Hatchell KE, Ormond KE, Hanson-Kahn A, et al. Physician-directed genetic screening to evaluate personal risk for medically actionable disorders: a large multi-center cohort study. BMC Med. 2021;19:199 https://doi.org/10.1186/s12916-021-01999-2.

The original article can be found online at https://doi.org/10.1186/s12916021-01999-2.

* Correspondence: eden.haverfield@invitae.com

${ }^{1}$ Invitae, 1400 16th Street, San Francisco, CA 94103, USA

Full list of author information is available at the end of the article

(c) The Author(s). 2021 Open Access This article is licensed under a Creative Commons Attribution 4.0 International License, which permits use, sharing, adaptation, distribution and reproduction in any medium or format, as long as you give appropriate credit to the original author(s) and the source, provide a link to the Creative Commons licence, and indicate if changes were made. The images or other third party material in this article are included in the article's Creative Commons licence, unless indicated otherwise in a credit line to the material. If material is not included in the article's Creative Commons licence and your intended use is not permitted by statutory regulation or exceeds the permitted use, you will need to obtain permission directly from the copyright holder. To view a copy of this licence, visit http://creativecommons.org/licenses/by/4.0/ The Creative Commons Public Domain Dedication waiver (http://creativecommons.org/publicdomain/zero/1.0/) applies to the data made available in this article, unless otherwise stated in a credit line to the data. 